\title{
ЕКОЛОГІЧНЕ ПРАВО
}

\section{ГРИГОР'СВА Х. А.,}

доктор юридичних наук,

доцент кафедри аграрного, земельного

та екологічного права

(Національний університет «Одеська

юридична академія»)

УДК 349.6

DOI https://doi.org/10.32842/2078-3736/2021.4.13

\section{НЕПРЯМА ЗМІНА ЗЕМЛЕКОРИСТУВАННЯ (ILUC) ВНАСЛІДОК РОЗВИТКУ БІОЕНЕ РГЕТИКИ: ПРАВОВИЙ РОЗРІЗ ПРОБЛЕМИ ${ }^{1}$}

Стаття присвячена виявленню сучасного та перспективного юридичного значення непрямих зміни землекористування (категорії ILUC), що виникають у результаті розвитку біоенергетики. Проаналізовано термінологічні проблеми визначення поняття ILUC. Досліджено досвід деяких країн світу (Європейського Союзу, Польщі, Бразилії, Індонезії, Малайзії), який був ними накопичений під час використання фактору непрямих змін землекористування у побудові їхнього біоенергетичного законодавства. Виявлено, що непрямі зміни землекористування мають потенціал для активного використання в ролі нетарифних торговельних бар'єрів нового покоління, які матимуть кліматоохоронний характер. Фактор непрямих змін землекористування не застосовується у вітчизняному законодавстві, однак й перспективі має стати концептуальною основою для становлення біоенергетичного законодавства України. Зроблено висновки про те, що наразі стоїть питання обрання принципових засад побудови біоенергетичного законодавства України. Задля успішного його формування мають бути опрацьовані та враховані здобутки вітчизняної та зарубіжної наукової доктрини, а також накопичений світовий досвід зокрема, у частині моделювання та запобігання непрямим змінам землекористування. При цьому існує потреба у розробці власної стратегії законодавчого забезпечення біоенергетичного розвитку України з урахуванням національних особливостей, передумов та проблемних аспектів. Проаналізовано три популярні стратегії побудови майбутнього біоенергетичного законодавства: 1) стратегія мімікрії під європейське законодавство; 2) стратегія обмеження та блокування розвитку біоенергетики; 3) стратегія ігнорування, яка є домінуючою на сучасному етапі. Ігнорування фактору ILUC, так само як і ігнорування необхідності продуманого та концептуально виваженого формування біоенергетичного законодавства призведе до виснаження природних ресурсів, загострення екологічних проблем, міжнародно-правового тиску в перспективі.

Ключові слова: біоенергетика, непрямі зміни землекористування, ILUC, альтернативна енергетика, відновлювана енергетика, енергетичне законодавство, екологічне право, земля, охорона довкілля.

1 Дослідження проведене в межах виконання проекту «Альтернативна енергетика в Україні: шляхи системного законодавчого стимулювання», за фінансової підтримки Національного фонду досліджень України (договір № 30/02/0360 від 28.04.2021 року)

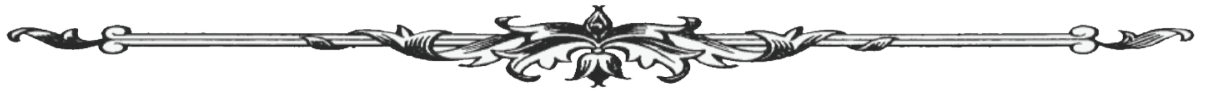


Hryhorieva Kh. A. Indirect land use changes (ILUC categories) arising from
the development of bioenergy: legal part of the problem
The article is devoted to identifying the current and future legal significance of indirect land use changes (ILUC categories) arising from the development of bioenergy. The author analyzes the terminological problems of defining the concept of ILUC. The experience of some countries of the world (European Union, Poland, Brazil, Indonesia, Malaysia), which they have accumulated during the use of the factor of indirect land use changes in the construction of their bioenergy legislation, is studied. Indirect land use change has the potential to be actively used as a next-generation non-tariff trade barrier to climate protection. The factor of indirect land use changes is not used in domestic legislation, but in the future, it should become a conceptual basis for the formation of bioenergy legislation in Ukraine. It is concluded that currently there is a question of choosing the basic principles of building bioenergy legislation of Ukraine. In order to form it, the achievements of domestic and foreign scientific doctrine, as well as the accumulated world experience - in particular, in terms of modeling and prevention of indirect land use changes - must be processed and taken into account. At the same time, there is a need to develop its own strategy for legislative support of bioenergy development of Ukraine, taking into account national characteristics, preconditions and problematic aspects. Three popular strategies for building future bioenergy legislation are analyzed: 1) mimicry strategy for European legislation; 2) strategy to limit and block the development of bioenergy; 3 ) the strategy of ignoring, which is dominant at the present stage. Ignoring the ILUC factor, as well as ignoring the need for thoughtful and conceptually balanced formation of bioenergy legislation will lead to depletion of natural resources, exacerbation of environmental problems, international legal pressure in the future.

Key words: bioenergy, indirect land use change, ILUC, alternative energy, renewable energy, energy legislation, environmental law, land, environmental protection.

Вступ. Як і в усьому світі, розвиток біоенергетики в Україні - процес неоднозначний: з одного боку, його прийнято розуміти як одну з необхідних складових переходу до зеленої економіки («біоекономіки»), з іншого - цей шлях супроводжується багатьма складнощами, зокрема, виникають досить гострі екологічні, соціальні та економічні питання. Позитивні здобутки біоенергетики втілюються в іiі безсумнівних досягненнях та характеристиках: відновлюваності, низькому ступені забруднення довкілля, легкому масштабуванні, доступності тощо. Однак негативний бік біоенергетики, який розкрився протягом останніх десятирічь у різних країнах світу, змушує більш уважно аналізувати цей вид альтернативної енергетики. Головна іï загроза заключається у категорії непрямих змін землекористування, що в англомовній науковій літературі зводиться до абревіатури ILUC (англ. Indirect Land Use Change). У світловій науковій доктрині пік досліджень цієї проблеми припав на період 20052015 роки, це посприяло тому, що у багатьох країнах аналізований фактор стає домінантним при визначенні біоенергетичної політики та при формуванні відповідного законодавства.

В Україні біоенергетика розвивається без міцної опори на стабільне та передбачуване спеціальне законодавство. Це створює передумови для того, щоб зростаючий попит на біомасу у світі перетворив Україну на сировинного донора інших держав. Саме тому питання концептуального бачення побудови вітчизняного біоенергетичного законодавства надзвичайно нагальне для України. Основною віссю такої побудови має стати визначення правового виміру непрямих змін землекористування (ILUC), чому і присвячена дана стаття.

Питаннями правового забезпечення розвитку альтернативної енергетики в Україні займалися такі учені, як С.Д. Білоцький, Х.А. Григор’єва, Г.Д. Джумагельдієва, К.М. Караханян, О.Б. Кишко-Срлі, О.І. Кулик, С.А. Оболєнська, А.В. Павлига, А.В. Пастух, С.О. Платонова,

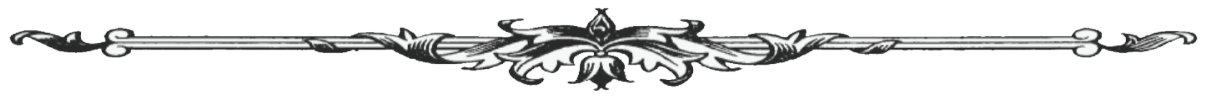


Е.Ю. Рибнікова, Ю.М. Рудь, О.М. Савельєва, М.В. Чіпко, І.Є. Чумаченко, Т.Є. Харитонова, Г.І. Шматько та інших. При цьому проблемам протидії непрямим змінам землекористування приділялася епізодична увага. Це сформувало нагальну потребу у комплексних дослідженнях впливу ILUC на становлення біоенергетичного законодавства нашої держави.

Постановка завдання. У зв'язку із цим метою статті стало виявлення юридичного значення категорії ILUC - непрямих змін у землекористуванні, породжених розвитком біоенергетики в Україні та світі.

Результати дослідження. Незважаючи на високий інтерес до окресленої проблеми, вичерпного наукового визначення ILUC досі не сформовано. Насправді, це більше закономірно, ніж дивно. Розвиток біоенергетики підштовхнув учених і практиків до підрахунку усіх вигод та збитків від біоенергетичної діяльності. Причому не лише очевидних, але й що найголовніше - непрямих. Такі непрямі наслідки можуть набувати різних конкретних форм. Найбільш загрозливі приклади полягають у тому, що біоенергетика, потребуючи для свого розвитку розширення площ земельних угідь, конкурує з існуючими видами землекористування - сільськогосподарським, лісогосподарським, природоохоронним - тобто біоенергетика вимушена боротися за перерозподіл існуючих площ - унаслідок цього часто страждає або продовольча безпека, або екологія. Хрестоматійним став приклад із уявною країною, яка перепрофілює своє сільське господарство на вирощування енергетичних культур, і цим самим закономірно зменшує виробництво продовольчої кукурудзи. Це потягне за собою зростання продовольчого попиту на кукурудзу в цій країні, а значить - в інших державах будуть розчищатися додаткові площі для вирощування кукурудзи 3 метою задоволення цього попиту. Таким чином, екологічний ефект від переходу до біоенергетики в першій країні знівельовано непрямою зміною землекористування в інших країнах.

Коли було виявлено такі непрямі ефекти розвитку біоенергетики, виникла потреба в їх узагальненні та вивченні. Саме тому з'явилося поняття ILUC як збірна категорія, рамки якої ніхто чітко визначити не може, оскільки вона означає потенційну загрозу, яку слід за можливості передбачити, оцінити та зважити ії наслідки. Зокрема, в деяких наукових дослідженнях було продемонстровано, що ILUC може легко створити ситуацію, коли біопаливо призводить до більшої кількості викидів парникових газів, ніж їх аналог викопного палива, якщо його не контролюють належним чином і не враховують у кліматичній політиці [1].

3 іншого боку, існує низка учених, які переконують у надуманості проблеми. Вони вважають, що через свою ефімерність та невизначеність ILUC не може використовуватися у державній кліматичній політиці [2]. Однак при цьому не варто забувати про те, що «політики, що працюють в Свропі та за ії межами, використовують біопаливо з інших причин, крім екологічних. Це новий і простий спосіб дати субсидії фермерам, і це також пов'язано 3 промисловими лобі, які виробляють біодизель» [3; 4]. Включення фактору ILUC до критеріїв стійкості може підірвати галузеві групи, які лобіювали цілі щодо біопалива, і тому його намагаються знецінити.

ILUC як фактор побудови біоенергетичного законодавства (світовий досвіd). Ступінь врахування фактору ILUC має правове значення, а саме: від того, наскільки грунтовно опрацьовані можливі наслідки розвитку біоенергетики в країні залежить змістовне наповнення законодавства: а) буде воно стимулюючим чи стримуючим; б) які напрями діяльності будуть заохочуватися, а які - заборонятися; в) які бар'єри та рамки будуть встановлені, тощо.

Традиційно у вітчизняній доктрині еталонним вважається законодавство ЄС. Стратегія, покладена в основу сучасного європейського законодавства, полягає у якомога більш точному врахуванні ILUC-ефекту. Для врівноваження енергетичних, екологічних, економічних та соціальних проблем, які супроводжують розвиток біоенергетики, ЄС обирає шлях обмеження використання сільськогосподарських культур з одночасним збільшенням використання органічних залишків [5]. Це підвищує інтерес до біопаливних сировинних ресурсів, які не спричиняють ILUC: наприклад, залишки, врожаї з раніше невикористовуваних орних земель, додаткові культури [6]. Звичайно, такий підхід встановлює рамки для розвитку біоенергетичного сектору, обмежує його масштаби.

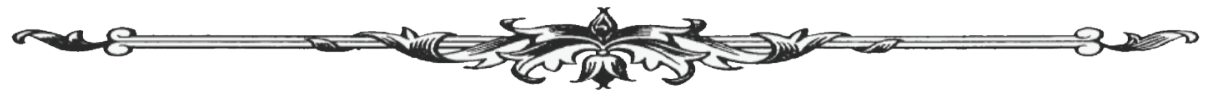


При аналізі європейського досвіду особливо слід звернути увагу на еволюцію відповідного законодавства [7]. Справа у тому, що вимоги, прив’язані до ILUC-ефекту, варто розглядати у характерному історико-правовому контексті, адже їх становлення не було позбавлене помилок та прорахунків. Так, стимулювання біоенергетики на початковому етапі не мало стримуючих рамок, втілених у зважуванні усієї сукупності майбутніх наслідків. Це призвело до того, що протягом короткого періоду часу у сферу біоенергетики було вкладено значні інвестиції, однак ці капіталовкладення були зроблені переважно у виробництво біопалива першого покоління (традиційні сільськогосподарські культури з високим вмістом жирів, крохмалю, вуглеводів, які переробляються у біодизель та етанол). Однак невдовзі стало зрозуміло, що бурхливий розвиток біоенергетики першого покоління не є екологічно дружнім та викликає багато сумнівів у своїй кліматоохоронній цінності, і тому державна політика змінилася, зокрема через непрямі зміни землекористування. У відвертій заяві EurActive головний автор звіту IFPRI за 2011 p. Laborde добре підсумував проблему СC: «Ми почали проводити політику, не знаючи, який ефект це матиме .... Зараз ми обговорюємо ефект використання землі після того, як протягом десяти років говорили, що нам потрібно біопаливо для зменшення викидів. Це була серйозна помилка» [3; 4$]$.

При цьому нове законодавство, яке досить грунтовно опирається на аналіз ILUC-фактору, запроваджувалося в СС з повагою до бізнесу, який виріс на попередньому державному стимулюванні. Було обрано політику здебільшого м’ якого стимулювання, що створило адаптивний період для переорієнтації біоенергетичного сектору на нові екологічні вимоги. В якості ілюстрації можна навести приклад з європейського правового досвіду. Так, Директивою 2009/28/СС було поставлено обов'язкову ціль по досягненню щонайменше 10\% енергії з відновлюваних джерел енергії у транспортному секторі до 2020 року. При цьому частка біопалив, вироблених з харчових сільськогосподарських культур, мала становити не більше 7\% кінцевого енергоспоживання на транспорті, а для біопалив, отриманих з відходів, залишків, нехарчової целюлозної сировини та лігноцелюлозної сировини, передбачалося подвійне зарахування у виконання цілі 2020 року. У такий спосіб, уникаючи жорстких заборон, нормотворець намагався «підштовхнути», вмотивувати та зробити доцільним обраний пріоритетний напрям біоенергетичного розвитку [8].

При цьому кліматичні амбіції ЄС тільки зростають, особливо на тлі проголошення Green Deal [9; 10]. Кожна країна - член ЄС має національні завдання та визначені критерії і строки для його виконання. Активне використання ILUC-моделювання досить сильно впливає на національне законодавство. Це, зокрема, добре проглядається на прикладі Польщі. Протягом певного часу Польща виконувала свої національні зобов'язання перед ЄС. Однак, щоб відповідати вимогам, які почали діяти після 2020 року, їй необхідно вишукувати додаткові шляхи [11], оскільки традиційний ріпаковий біодизель буде недостатньо сталим та екологічним, а значить не виконуватиме національні біоенергетичні завдання.

Отже, будь-які дії законодавця спричиняють той чи інший ефект, і це дуже рельєфно простежується на прикладі біоенергетики. Так, встановлення в СС чітко обрахованих цілей споживання потягло зростання попиту на біопаливо. У Бразилії стимулювання виробництва етанолу потягло зростання площ під цукровою тростиною, а це в свою чергу відсунуло тваринництво до лісового кордону, тобто спровокувало розчищення території для пасовищ [12]. Бурхливий розвиток біоенергетики на основі виробництва пальмової олії в Індонезії та Малайзії поряд зі значними позитивними результатами спричинив цілий комплекс екологічних та соціальних проблем [13; 14]. Усі ці наслідки мають єдиний знаменник у непрямих змінах землекористування.

ILUC як привід введення кліматоохоронних нетарифних бар'єрів. Знову ж таки, на прикладі біоенергетики стало остаточно зрозуміло, що екологічні проблеми, які мають в своїй основі ILUC, не є суто національними, і правовий суверенітет держав у цих питаннях все більше розмивається. Найкраще це ілюструється прикладом Індонезії та Малайзії, які у 2019 та 2021 роках оскаржили запроваджені Європейським Союзом заборони на імпорт їхніх пальмової олії та біопалива, що мотивувалися недостатньою сталістю такої продукції,

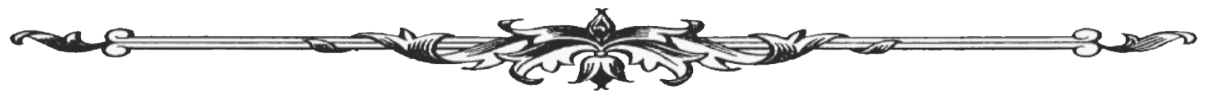


а саме: іiї виробництво супроводжується непрямими змінами землекористування $[15 ; 16]$. Виникнення подібних конфліктів неминуче. Більш того, вони стануть частішими. Невизначеність поняття ILUC, різні підходи до його моделювання та обчислення стануть приводом для активного використання нових торговельних нетарифних бар'єрів кліматоохоронного характеру. У зв'язку з тим, що досі не опрацьовано певну уніфіковану методологію визначення ILUC, цілком ймовірно, що, по-перше, країни будуть застосовувати ті підходи, які вигідні їм, а по-друге, будуть користуватися науковою невизначеністю і приховувати під кліматоохоронними бар'єрами економічні та торгові протекційні інструменти. Це, у свою чергу, може у перспективі підривати авторитет кліматоохоронних заходів.

Звичайно, наростання цих проблем безпосередньо стосується питань ліберальної торгівлі, тобто питань відповідності національного законодавства (у т.ч. біоенергетичного) праву СОТ. Тут проявляться одразу кілька складних проблем: 1) проблема безпорадності COT, що поглиблюється внаслідок кризи, яка охопила організацію через блокування роботи органу вирішення спорів; 2) непристосованість права СОТ до вирішення екологічних проблем - його основна мета полягає у подальшій лібералізації торгівлі, а будь-які природоохоронні бар'єри сприймаються вороже та піддаються жорсткій перевірці. Якщо організація не зробить суттєву трансформацію власних підходів та концептуального бачення врегулювання міжнародних торговельних відносин, «правила СОТ діятимуть як сила, що підриває політику зменшення викидів» [4].

ILUC ma біоенергетичне законодавство в Украӥні. У світлі окреслених світових тенденцій аналіз вітчизняних доктринальних та законодавчих основ демонструє деякі проблемні аспекти. Наприклад, мова йде про брак відповідних наукових розвідок. Щодо проблем, які супроводжують розвиток біоенергетики, висловлювалися думки у дисертаціях С.А. Оболєнської [17], А.В. Пастух [18], Е.Ю. Рибнікової [19], однак вони стосувалися переважно питань сталості біомаси. ILUC - це більш об'ємна категорія, яка окрім цього охоплює значно більш віддалені наслідки біоенергетичного розвитку.

Окремі думки стосовно непрямих змін землекористування висловлювалися побічно, в контексті розгляду інших правових проблем: збереження біорізноманіття (І.В. Гиренко, Н.Р. Малишева, А.К. Соколова, Е.С. Туліна, С.А. Шарапова, В.В. Шеховцов та інші), відновлення земель і грунтів (Н.С. Гавриш, І.І. Каракаш, П.Ф. Кулинич, Т.В. Лісова, В.В. Носік та інші), збільшення лісистості (А.П. Гетьман, М.М. Заверюха, Л.В. Мендик, М.В. Шульга та інші), розширення площ природно-заповідного фонду (А.Й. Годованюк, О.М. Ковтун, Н.В. Фролова, А.І. Черемнова та інші), екологізації сільськогосподарської діяльності (О.В. Гафурова, В.М. Єрмоленко, Н.В. Кравець, Ю.А. Краснова, Т.В. Курман, А.М. Статівка тощо). При цьому слід констатувати відсутність комплексних досліджень, спрямованих на правове забезпечення процесів моделювання непрямих змін землекористування, врахування цих результатів у практичній діяльності, під час планування розвитку територій, під час розробки державної аграрної політики, під час управління використанням земельних та інших природних ресурсів.

Інертність доктрини у цьому напрямі наукових досліджень певною мірою негативно відображається на законодавчих засадах регулювання відносин землекористування. Зокрема, сучасне реформування земельного законодавства у частині цільового призначення земель лише загострить проблему непрямих змін землекористування. Прийнятий нещодавно Верховною Радою Закон № 1423-IX (законопроект № 2194) «Про внесення змін до Земельного кодексу України та інших законодавчих актів щодо удосконалення системи управління та дерегуляції у сфері земельних відносин» спрощує процедури зміни цільового призначення земельних ділянок приватної власності і у цій частині не повною мірою узгоджується із іншими новітніми земельними законами, зокрема, із Законом України «Про внесення змін до деяких законодавчих актів України щодо планування використання земель» [20]. Непідготовлена належним чином та грунтовно не виважена лібералізація відносин у сфері зміни цільового використання земель може стати досить вагомим фактором прискорення непрямих змін землекористування в Україні. Особливо ці занепокоєння посилюються на тлі

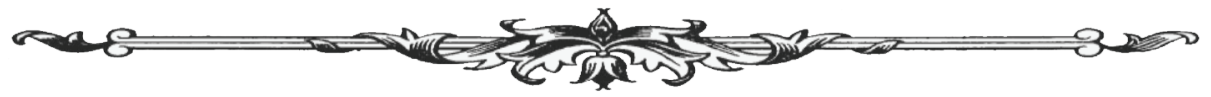


слабкості контролюючих інституцій екологічного профілю, що теж формує несприятливі передумови для становлення біоенергетики в нашій державі. О. Г. Бондар прозорливо вбачає високий ризик інституційного послаблення системи контрольно-наглядової діяльності щодо земель у тій частині, яка передається на рівень громад [21]. Відтак в Аналітичній записці «Належне екологічне врядування в країнах Східного партнерства: роботи непочатий край», підготовленій зарубіжними та вітчизняними експертами, доречно вказано, що адміністративні реформи в цих країнах подекуди ослабили інституційну структуру у сфері охорони навколишнього природного середовища, та наголошено на необхідності стежити за тим, щоб дерегуляція в рамках цих реформ не призводила до збільшення ризиків для навколишнього середовища [22, с. 6-7].

Отже, в результаті відсутності концептуально-методологічного розуміння проблем непрямих змін землекористування, що відбуваються внаслідок розвитку біоенергетики, в Україні відсутнє системне та виважене біоенергетичне законодавство. Існує кілька популярних, але в корені невірних стратегій дій відносно утворення відповідного законодавства, яких варто уникати вітчизняному нормотворцю:

1) мімікрія під європейське законодавство. Пряме копіювання сучасних європейських правових зразків - це шлях до вбивства вітчизняної біоенергетики в зародку: європейське законодавство пройшло необхідний еволюційний шлях разом із бізнесом та суспільством. При цьому співпраця із ЄС дозволяє Україні вчитися розробляти власні, національно обумовлені цілі розвитку, уникаючи бездумного переписування іноземних правових текстів;

2) жорсткі обмеження та блокування розвитку біоенергетики. Цей спосіб є спокусливим для нормотворця, адже замість складного процесу створення гармонійного правового забезпечення можна застосувати грубу заборону. Наприклад, навіщо намагатися узгоджувати інтереси бізнесу, суспільства і держави, вирішуючи проблеми непрямих змін землекористування, якщо можна просто заборонити вирощувати ріпак? Ми переконані, що стосовно розвитку біоенергетики жорстке імперативне втручання не матиме позитивного ефекту, а навпаки - здатне спровокувати тіньовий розвиток та консервацію сировинного характеру виробництва [8]. До речі, в Бразилії суттєве сповільнення вирубки лісів відбулося лише тоді, коли законодавець визнав їх охорону національним пріоритетом [2]: тобто було зосереджено увагу на охороні лісів, а не на війні з біоенергетикою;

3) ігнорування. Ця стратегія полягає в самоусуненні нормотворця від процесу правового забезпечення біоенергетичних відносин. Однак ця стратегія (вона, до речі, є домінантною зараз в Україні), незважаючи на свою ліберальну привабливість, є згубною. Відмовляючи біоенергетиці в законодавчому регулюванні, держава не припиняє іiі розвиток, а втрачає контроль над ним, власноруч перетворюючи цю чутливу сферу в стихійно організовану та спрямовану галузь економіки, яка породжує стрімкі непрямі зміни землекористування.

3 огляду на вищезазначене, на наш погляд, найбільш оптимальною можна назвати стратегію поступового формування біоенергетичного законодавства України. По-перше, біоенергетичне законодавство має вдумливо та концептуально вибудовуватися вже зараз. Однією з його методологічних засад слід вказати максимально можливий уклін у бік економіко-правового стимулювання та партнерських відносин бізнесу і держави. По-друге, особливо важливо також організувати системний управлінський підхід на основі створення спеціалізованого органу. Це стане запорукою стабільного управлінського середовища, комплексного підходу та урахування аграрних, енергетичних, господарських, міжнародно-правових особливостей становлення та подальшого масштабування біоенергетичної сфери в Україні [8]. По-третє, методологічною основою має бути стимулювання якомога меншого ILUC-впливу внаслідок розвитку біоенергетики.

Висновки. Отже, в результаті проведеного дослідження можна зробити висновок про те, що наразі стоїть питання обрання принципових засад побудови біоенергетичного законодавства України. Задля успішного його формування мають бути опрацьовані та враховані здобутки вітчизняної та зарубіжної наукової доктрини, а також накопичений світовий досвід - зокрема, у частині моделювання та запобігання непрямим змінам землекористування. При цьому існує

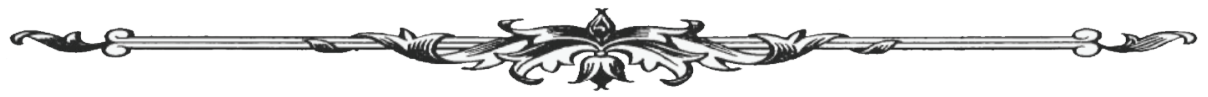


потреба у розробці власної стратегії законодавчого забезпечення біоенергетичного розвитку України з урахуванням національних особливостей, передумов та проблемних аспектів. Ігнорування фактору ILUC, так само як і ігнорування необхідності продуманого та концептуально виваженого формування біоенергетичного законодавства, призведе до виснаження природних ресурсів, загострення екологічних проблем, міжнародно-правового тиску в перспективі.

\section{Список використаних джерел:}

1. Searchinger T, Heimlich R, Houghton RA, Dong F, Elobeid A, Fabiosa J et al. Use of US croplands for biofuels increases greenhouse gases through emissions from land-use change. Science. 2008. Vol. 319. P. 1238-1240.

2. Zilberman D. Indirect land use change: much ado about (almost) nothing. URL : https://onlinelibrary.wiley.com/doi/10.1111/gcbb.12368 (дата звернення: 15.06.2021 року).

3. EU Report Questions Conventional Biofuels' Sustainability, supra n. 15.

4. Lydgate E. The EU, the WTO and Indirect Land Use Change. Journal of world trade. 2013. Vol. 47. № 1. P. 159-186.

5. Lantz M., Prade T., Ahlgren S., Björnsson L. Biogas and Ethanol from Wheat Grain or Straw: Is There a Trade-Off between Climate Impact, Avoidance of iLUC and Production Cost? Energies. 2018. Vol. 10. Issue 11.

6. Prade T., Björnsson L., Lantz M., Ahlgren S. Can domestic production of iLUC-free feedstockfrom arable land supply Sweden's future demandfor biofuels? Journal of land use science. 2017. Vol. 12. Issuê 6. P. 407-441.

7. Preziosi M., Merli R., Agar A. Evolution of european biofuels policy: adressing sustainability and indirect land-use change. URL : https://www.academia.edu/7172229/EVOLUTION_OF_EUROPEAN_BIOFUELS_POLICY_ADRESSING_SUSTAINABILITY_AND_ INDIRECT_LAND_USE_CHANGE (дата звернення:15.06.2021 року).

8. Харитонова Т. $\overline{\mathcal{C}}$., Григор'єва Х.А. Біоенергетичне законодавство в Україні - перспектива бути. П'яте зібрання фахівиів споріднених кафедр з проблем аграрного, земельного, екологічного, природоресурсного права та альтернативної енергетики : матер. Всеукр. наук. конф. (м. Одеса, 10-13 червня 2021 року) / відп. ред. Т.Є. Харитонова, Х.А. Григор'єва. Одеса : Видавничий дім «Гельветика», 2021. С. 102-106.

9. Харитонова Т.Є., Григор'єва Х.А. Енергетичний складник українського Green Deal: аналіз правових передумов. Юридичний науковий електронний журнал. 2021. № 2. C. 149-154.

10. Григор'єва X. A. Green Deal та Україна: роздуми про правові перспективи. Екологічне право. 2021. № 1.

11. Indirect land-use change effects of biodiesel production: A case study for Poland. URL : https://www.wflpublisher.com/Abstract/5342 (дата звернення15.06.2021 року).

12. Andrade de Sá S., Palmer C., Di Falco S. Dynamics of indirect land-use change: Empirical evidence from Brazil. Journal of Environmental Economics and Management. 2013. Vol. 65(3). P. 377-393.

13. Григор'єва Х.А. Готовність законодавства до світового розвитку біоенергетики (на матеріалах України, ЄС та Малайзії). Актуальні питання стратегї державної екологічноі політики України на період до 2030 року: матер. кругл. столу (Харків, 21 травня 2021 року). Харків, 2021. С. 41-45.

14. Григор’єва Х.А., Дубінін Ю.С. Біоенергетика в Індонезії: економіко-правові та соціально-екологічні уроки для України. П’яте зібрання фахівців споріднених кафедр 3 проблем аграрного, земельного, екологічного, природоресурсного права та альтернативної енергетики : матер. Всеукр. наук. конф. (м. Одеса, 10-13 червня 2021 року) / відп. ред. Т.Є. Харитонова, Х.А. Григор’єва. Одеса : Видавничий дім «Гельветика», 2021. С. 30-33.

15. European Union - Certain measures concerning palm oil and oil palm crop-based biofuels. URL : https://www.wto.org/english/tratop_e/dispu_e/cases_e/ds593_e.htm (дата звернення: 15.06.2021 року).

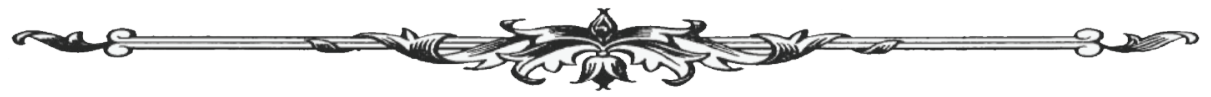


16. European Union and certain Member states - Certain measures concerning palm oil and oil palm crop-based biofuels. URL : https://www.wto.org/english/tratop_e/dispu_e/cases_e/ ds600_e.htm (дата звернення: 15.06.2021 року).

17. Оболєнська С.А. Правове регулювання виробництва біопалива сільськогосподарськими товаровиробниками в Україні : автореф. дис. ... канд. юрид. наук : 12.00.06. Харків, 2017. $20 \mathrm{c}$.

18. Пастух А.В. Правове регулювання вирощування та перероблення сільськогосподарської сировини для виробництва біопалива : автореф. дис. ... канд. юрид. наук : 12.00.06. Київ, 2017. 18 с.

19. Рибнікова Е.Ю. Господарсько-правове стимулювання використання відновлюваних джерел енергії в Україні : автореф. дис. ... канд. юрид. наук 12.00.04. Одеса, 2018. 20 с.

20. Годованюк А.Й. Цільове призначення «до» і «після». П'яте зібрання фахівціів споріднених кафедр з проблем аграрного, земельного, екологічного, природоресурсного права та альтернативної енергетики : матер. Всеукр. наук. конф. (м. Одеса, 10-13 червня 2021 року) / відп. ред. Т.Є. Харитонова, Х.А. Григор'єва. Одеса : Видавничий дім «Гельветика», 2021. С. 135-137.

21. Бондар О.Г. Актуальні правові проблеми контрольно-наглядової діяльності в земельній сфері в умовах децентралізації. П’яте зібрання фахівців споріднених кафедр 3 проблем аграрного, земельного, екологічного, природоресурсного права та альтернативної енергетики : матер. Всеукр. наук. конф. (м. Одеса, 10-13 червня 2021 року) / відп. ред. Т.Є. Харитонова, Х.А. Григор'єва. Одеса : Видавничий дім «Гельветика», 2021. С. 15-18.

22. Належне екологічне врядування в країнах Східного партнерства : роботи непочатий край : Аналітична записка. URL : https://www.irf.ua/ukraina_posila_trete_mistse_sered krain_skhidnogo_partnerstva_u_zdiysnenni_ekologichnikh_reform/files/ukr/programs/euro/ toloka_env_gov.pdf (дата звернення: 27.05.2021).

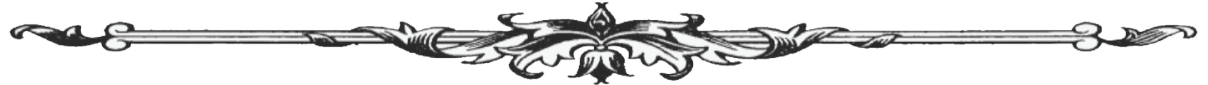

